\title{
Factors Affecting Poultry Meat Consumption Status and Consumption Habits of Students From Faculty of Veterinary Medicine
}

\author{
Ahmet Cumhur AKIN*, Mustafa Bahadır ÇEVRİMLİ², Burak MAT², Mehmet Saltuk ARIKAN³, \\ Mustafa Agah TEKINDAL ${ }^{4}$
}

\author{
${ }^{1}$ Mehmet Akif Ersoy University, Veterinary Medicine Faculty, Animal Health Economics and Management Department, 15030, \\ Burdur, Turkey \\ ${ }^{2}$ Selcuk University, Veterinary Medicine Faculty, Livestock. Economics and Management Department, 42003, Konya, Turkey \\ ${ }^{3}$ Furat University, Veterinary Medicine Faculty, Animal Health Economics and Management Department, 23119, Elazrğ, Turkey \\ ${ }^{4}$ SelcukUniversity, Veterinary Medicine Faculty, Biostatistic Department, 42003, Konya, Turkey
}

\begin{abstract}
This research was carried out to in Burdur, Elazığ and Konya provinces in order to evaluate the factors affecting the poultry meat consumption status and consumption habits of students belonging to different classes of veterinary faculties. The material of the study was obtained from surveys conducted with 242 students in three different faculties during the academic year 2018-2019. The data were analyzed by SPPS. According to the results of the research; It has been determined that $51.7 \%$ of the students are under $250 \mathrm{TL}$ of the monthly individual food expenditure. The ratio of animal food expenditures in individual food expenditures of those students to be $100 \mathrm{TL}$ and below is determined as $59.1 \%$. When the monthly poultry meat consumption rates of the students are examined; The rate of those who did not consume was $5.8 \%$, the rate of those consuming less than $500 \mathrm{gr}$ and $31 \%$ of those consuming $500-999 \mathrm{gr}$ was determined as $37.2 \%$. It was determined that the students who participated in the survey consumed $1.1 \mathrm{~kg}$ of poultry meat per month. It was determined that there was no statistically significant relationship between the poultry meat consumption and the city, class level and shelter status of the students. In fact, a statistically significant relationship was found between the gender, income level, monthly budget for food and amount of monthly budget allocated to animal food.
\end{abstract}

Keywords: Poultry Meat, Income, Consumption, Consumer Preference, Veterinary Faculty

Veteriner Fakültesi Öğrencilerinin Beyaz Et Tüketimi Üzerine Etki Eden Faktörlerin Değerlendirilmesi

ÖZ

Bu araștırma, Burdur, Konya ve Elazı̆̆ illerinde yer alan üniversitelerin veteriner fakültelerinde eğitim görmekte olan farklı sınıflardaki ögrencilerin kanatlı eti tüketim düzeylerine etkili olan faktörlerin güncel olarak ortaya konması amacıyla yapılmıştır. Araştırmanın materyalini, 2018-2019 eğitim-öğretim yılı içerisinde üç farklı fakültede toplamda 242 öğrenci ile yapılmış olan anketlerden elde edilen veriler oluşturmaktadır. Elde edilen veriler SPPS programı ile analiz edilmiștir. Araşıırma sonucunda; öğrencilerin \%51,7’sinin aylık bireysel gıda harcama tutarının 250 TL altında olduğu belirlenmiştir. Yine bu öğrencilerin bireysel gıda harcamaları içerisinde hayvansal gıta harcama tutarlarının 100 TL ve altında olanların oranı ise \%59,1 olarak bulunmuștur. Öğrencilerin ayllk kanatlı eti tüketim oranları incelendiğinde; hiç tüketmeyenlerin oranı \%5,8, 500 gr'dan az tüketenlerin oranı \%31 ve 500-999gr arası tüketenlerin oranı ise $\% 37,2$ düzeyinde tespit edilmiştir. Ankete katılan öğrencilerin aylık ortalama $1,1 \mathrm{~kg}$ kanatlı eti tükettikleri belirlenmiştir. Öğrencilerin eğitim gördükleri şehir, sinıf düzeyi ve barınma durumları ile kanatlı eti tüketim miktarı arasında istatistiki olarak anlamlı bir ilişkinin olmadığı belirlenmiştir. Nitekim, cinsiyet, gelir düzeyi, gıda maddelerine ayrılan aylık bütçe ile hayvansal gıdalara ayrılan aylık bütçe miktarı arasında istatistiki olarak anlamlı bir ilișkinin olduğu belirlenmiștir.

Anahtar Kelimeler: Beyaz et, Gelir, Tüketim, Tüketici Tercihi, Veteriner Fakültesi

To cite this article: Akin A.C. Cevrimli M.B. Mat B. Arkean M.S. Tekindal M.A. Factors Affecting Poultry Meat Consumption Status and Consumption Habits of Students From Faculty of Veterinary Medicine. Kocatepe Vet J. (2019) 12(4):456-462.

Submission: 30.10.2019 Accepted: 27.11.2019 Published Online: 01.12.2019

ORCID ID; ACA: 0000-0003-3732-0529, MBÇ: 0000-0001-5888-242X, BM: 0000-0002-0455-8736,

MSA: 0000-0003-4862-1706, MAT: 0000-0002-4060-7048

*Corresponding author e-mail: acumhurakin@mehmetakif.edu.tr 


\section{GİRİŞ}

Ulusal g1da arzı ile toplumun yeterli ve dengeli beslenmesinde, hayvancllı sektörü önemli görevler üstlenmektedir. Bu bağlamda ülkelerin gelişmişlik düzeylerinin belirlenmesinde dikkate alınan kıstaslardan birisi de kişi başına düşen hayvansal protein tüketim miktarıdır (Akçay ve ark. 2018). Ancak Türkiye'de gida maddelerine ulaşabilirdik başta temel gidalar olmak üzere birçok üründe yetersiz kalmaktadır. $\mathrm{Bu}$ yetersizlik en çokta et ve et ürünlerinde dikkati çekmektedir. OECD ve Türkiye'de kişi başı et tüketim istatistikleri incelendiğinde; OECD ülkelerinde sığır eti $14.62 \mathrm{~kg}$, koyun eti $1.34 \mathrm{~kg}$ ve tavuk eti $30.7 \mathrm{~kg}$ tüketilirken, Türkiye'de bu miktarlar sirasiyla $8.57 \mathrm{~kg}$, $4.36 \mathrm{~kg}$ ve $19.4 \mathrm{~kg}$ düzeyinde olduğu görülmektedir (Anonymous 2019). Türkiye'de son dönemde kırmızı et fiyatlarında yaşanan artışlar (Arıkan ve ark. 2019), tüketicilerin yeterli ve dengeli beslenmeleri için gerekli olan kırmızı ete ulaşılabilirliği büyük oranda kıstllamıştır (Akın ve ark. 2019). Gıda fiyatlarında yaşanan artışlar dar gelirli tüketicilerin düzenli gıda tüketimini olumsuz etkilemekte (Hernandez ve ark. 2011, Eştürk ve Albayrak 2018), ve toplumun beslenme tercihlerinde değişikliklere yol açmaktadır (Sarris 2013, Bazga ve ark. 2014). Türkiye'de hayvancllı alt sektörlerinden, kanatlı sektörünün uyguladığı üretim modeli, insanların hayvansal proteini en sağlıklı ve en kısa sürede temin etmesinde önemli bir görev üstlenmiştir (Kızılaslan ve Nalıncı 2013). Bu nedenle günümüzde kişi başına hayvansal protein tüketiminde önemli gıdaların başında kanatlı eti yer almaktadır. Kırmızı etin ikame ürünü konumunda olan tavuk etinin (Erdoğdu ve Çiçek 2017), tüketim miktarını etkileyen çok sayıda faktör vardır. Bunlar bölgesel kalkınma farklılıkları, tüketici gelir düzeyi, sosyoekonomik ve demografik faktörler, mevsimler, gıda güvenliği ve kalitesi, kişisel zevkler ve alışkanlıklar, ürün fiyatı ve insan sağlığı ile ilgili görüşler genellikle tavuk talebini etkileyen ana etkenler olarak görülmektedir (Aral ve ark. 2013). Dünyada kişi başı kanatlı eti tüketim miktarları ülkelerin gelişmişlik düzeyine bağlı olarak değişkenlik göstermektedir (İskender ve ark. 2015). Türkiye'de kanatlı eti, insanların hayvansal protein tüketimlerinde stratejik bir ürün haline gelmiştir. $\mathrm{Bu}$ durum kişi başı kanatlı eti tüketim rakamlarına yansımış olsa da gelişmiş ülkelerin hayli gerisinde kalmaktadır. Kişi başı kanatlı eti tüketim miktarı Türkiye'de 1990 yllında $6.8 \mathrm{~kg}$ düzeyinden başlayarak 2019 yllında $19.4 \mathrm{~kg}$ düzeyine ulaşırken Amerika Birleşik Devletleri için 1990 yılında 35 kg 2019 yllında ise $50.1 \mathrm{~kg}$ seviyesinde kanatlı eti tüketimi olduğu görülmektedir (Anonymous 2019).

Günümüz toplumlarının tüketim alışkınlarında yaşanan hızlı değişim ile birlikte insanların dengeli ve yeterli beslenmelerinde sıkıntılar yaşanmaktadır. İnsanların çocukluk ve gençlik çağları, sağlıklı yaşam tarzı ve beslenme alışkanlıklarının kazanıldığı yaşlar olması sebebi ile özel bir öneme sahiptir (Ayhan ve ark. 2012). Türkiye'de yeterli ve dengeli beslenme sorunlarıly sı karşılaşan gruplardan birisi de genç kesimdir (Cevger ve ark. 2008), bu bağlamda üniversite gençliği beslenme alıskanlıkları ele alındığında yetersiz ve dengesiz beslenme sorunları açısından risk arz eden gruplardandır (Ayhan ve ark. 2012).

Bu çalışma ile Burdur, Konya ve Elazığ illerinde yer alan üniversitelerin Veteriner Fakültesi'nde eğitim görmekte olan farklı sınıflardaki öğrencilerin kanatlı eti tüketim düzeylerine etkili olan faktörlerin güncel olarak ortaya konması hedeflenmektedir.

\section{MATERYAL ve METOT}

Araştırmanın materyalini Mehmet Akif Ersoy Üniversitesi (Burdur), Selçuk Üniversitesi (Konya) ve Firat Üniversitesi (Elazığ) Veteriner Fakültesi öğrencileri arasından tabakalı örneklem yöntemi ile belirlenmiştir (Botev ve Ridder 2017, Shahrokh Esfahani ve Doughert 2014).

$$
n_{0}=\frac{N t^{2} p q}{d^{2}(N-1)+t^{2} p q}
$$

Tablo 1'de fakültelerde hedeflenen ve gerçekleşen anket sayıları sunulmuştur.

Araştırma kapsamındaki 3 fakülteden asgari 114 öğrenci ile anket çalışması yapılması hedeflenmiş olup toplamda 242 kişi ile anket çalışması gerçekleştirilmiştir. Uygulanan ankette öğrencilere kaçınc1 sınıfta okudukları, barınma durumları, tüketmiş oldukları hayvansal gidaları miktar olarak yeterli bulup-bulmadıkları, aylık bireysel gelir, aylık bireysel gida harcama ve aylik bireysel hayvansal gida harcama aralıkları ile kanatlı eti tüketim miktarlarına ilişkin sorular yönlendirilmiştir.

Verilerin değerlendirilmesinde SPPS 25 (IBM Corp. Released 2017. IBM SPSS Statistics for Windows, Version 25.0. Armonk, NY: IBM Corp.) istatistik paket programı kullanılmıştır. Değişkenler medyan (IQR) yüzde ve frekans değerleri sunulmuştur. Kategorik veriler Ki Kare testi ile analiz edilmiştir. Beklenen frekansların \%20'den küçük olduğu durumlarda bu frekansların analize dâhil edilmesi için "Ki Kare testi Monte Carlo Tahmin Yöntemi" ile değerlendirme yapılmıştır. Kategoriler arasındaki farkliliklar Bonferroni düzeltmeli iki oran testi ile değerlendirilmiştir. Testlerin anlamllık düzeyi için $\mathrm{p}<0,05$ ve $\mathrm{p}<0,01$ değeri kabul edilmiştir. Yapılan bu çalısma Burdur Mehmet Akif Ersoy Üniversitesi Girişimsel Olmayan Klinik Araştırmalar Etik Kurulu'nun GO 2018/106 saylı kararı ile etik kurul onayı almıştır. 


\section{BULGULAR}

Araştırmaya 158 erkek (\%65,3), 84 bayan (\%34,7) olmak üzere toplam 242 öğrenci katılmıştır. Bu öğrencilerden 31’i (\%12,8) 1.sinıf, 60’1 (\%24,8) 2.sinıf, 49'u $(\% 20,2) 3 . s i n 1 f, 42$ 'si $(\% 17,4) 4$.sinif ve geriye

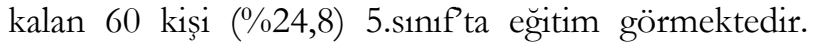
Barınma durumları incelendiğinde \%12'si ailesinin yaninda, $\% 2,1$ 'i akrabasinda, $\% 16,1$ 'i devlet yurdunda, $\% 12$ 'si özel yurtta ve geriye kalan \%56,6'llk çoğunluk ise öğrenci evinde kaldıklarını bildirmişlerdir.

Öğrencilerin aylık gelir ortalamaları 970,02 TL, bireysel aylik gida harcama ortalamalar1 305,14 TL, hayvansal gidalara yaptıkları ortalama harcama miktarı 113,64 TL olarak hesaplanmıştır. Öğrencilerin \%5,8’i hiç kanatlı eti tüketmediğini, \%31'i 500 gr'dan az, \%37,2'si 500-999 gr, \%15,7'si 1-2 kg, \%10,3'ü ise $2 \mathrm{~kg}$ üzerinde ayllk tüketiminin olduğunu bildirmiştir. Ortalama kanatlı eti tüketim miktarları aylık $1,1 \mathrm{~kg}$ düzeyinde olup, öğrencilerin \%60,7'si tükettiği aylık toplam hayvansal gida miktarını yetersiz olarak değerlendirmektedir.

Araştırma kapsamındaki veteriner fakültesi öğrencilerinin aylık tavuk ve hindi eti (kanatlı eti) tüketimine etkili olabileceği düşünülen faktörlerin değerlendirilmesine ilişkin bulgular Tablo 2'de sunulmuştur.

Tablo 2 incelendiğinde öğrencilerin öğrenim görmekte oldukları üniversitenin, sınıf düzeyinin ve barınma durumu ile kanatlı eti tüketim miktarları arasında istatistiksel olarak anlamlı bir ilişki bulanamamıştır. Erkeklerin bayanlara göre kanatlı eti tüketim düzeyi daha yüksek olup, cinsiyet ile tüketim düzeyi arasında anlamlı bir ilişki olduğu $(\mathrm{p}<0.05)$ görülmektedir. Erkek öğrencilerin 1000 gr ve üzeri aylık bireysel kanatlı eti tüketim miktarı oran1 $\% 32,3$ iken bu oran bayan öğrencilerde $\% 14,3$ olarak tespit edilmiştir.
Tablo 3’te öğrencilerin aylık gelir, bireysel aylık gida harcamas1 ve bireysel aylik hayvansal gidalara yaptıkları harcama aralıkları, miktarları ile kanatlı eti tüketim miktarına olan etkileri incelenmiştir.

Öğrencilerin aylık bireysel gelir aralığı, bireysel olarak g1da harcama aralığ1 ve aylık bireysel hayvansal gidalara harcama aralıkları ile kanatlı eti tüketim düzeyi arasında anlamlı bir ilişki olduğu $(p<0.05)$ belirlenmiştir. Aylık bireysel gelir miktarı arttıkça, bireysel gida harcama miktar1 ve hayvansal gidalara yapilan harcama düzeylerinin artmakta ve buna bağlı olarak öncelikle kanatlı eti tüketim miktarı artmaktadır. Öğrencilerin aylık 1000 gr ve üzeri kanatlı eti tüketim miktarı, aylık bireysel gelirleri 300 TL altı olan öğrencilerde \%8,6 iken bu oran 1500 TL üzerinde $\% 38,8$ olarak bulunmuştur. Bireysel aylık g1da harcama aralığ 150 TL altı olan öğrencilerde, 1000 gr ve üzeri kanatlı eti tüketim oranı \%11,9 iken bu oran 500 TL üstü olanlarda $\% 48,3$ düzeyinde gerçekleşmiştir. Bireysel aylık hayvansal gida harcamalar1 50 TL altı olan öğrencilerin, 1000 gr ve üzeri kanatlı eti tüketim oranı \%10 iken 300 TL üstü olanlarda \%66,6 olarak bulunmuştur.

Aylık bireysel gıda harcama aralığında gruplar arasında dengeli sayılabilecek bir dağglımın olduğu görülmektedir (Tablo 3). 150 TL altı, 150-199, 200249, 250-299, 300-499 TL ve 500 TL ve üzeri aylık g1da harcaması yapanların sirasılyla yüzde dağılımları (\%); 17,4, 19,8, 14,5, 14,9, 21,5 ve 12,0 olarak tespit edilmiştir.

Aylık bireysel hayvansal gidalara yapilan harcamalar incelendiğinde düşük harcama gruplarında birikimin olduğu dikkat çekmektedir. Şöyle ki aylık 50 TL altt, 50-99, 100-149, 150-199, 200-299 TL ve 300 TL üzeri harcama yapanların sırasıyla yüzde dağılımları (\%); $28,9, \quad 30,2, \quad 19,0, \quad 8,7, \quad 8,3$ ve 5,0 düzeyinde bulunmuştur.

Tablo 1. Hedeflenen ve uygulanan anketlerin üniversitelere dağılımı

Table 1. Distribution of targeted and applied surveys to universities

\begin{tabular}{lccc}
\hline Üniversite, Şehir & $\begin{array}{c}\text { Populasyon } \\
(\mathbf{N})\end{array}$ & $\mathbf{N}_{\mathbf{h}}$ & Ulaş1lan $\mathbf{~}_{\mathbf{h}}$ \\
\hline Mehmet Akif Ersoy Üniversitesi, Burdur & 515 & 29 & 60 \\
Selçuk Üniversitesi, Konya & 795 & 45 & 93 \\
F1rat Üniversitesi, Elazı̆g & 695 & 40 & 89 \\
\hline Toplam & 2005 & 114 & 242 \\
\hline
\end{tabular}


Tablo 2. Kanatlı eti tüketiminde etkili olabilecek faktörlerin değerlendirilmesi

Table 2. Evaluation of factors that may be effective in the consumption of poultry meat

\begin{tabular}{|c|c|c|c|c|c|c|c|c|c|c|}
\hline & \multirow[b]{2}{*}{ Faktörler } & & \multicolumn{5}{|c|}{ Aylık Bireysel Kanatlı Eti Tüketim Aralığ1 } & \multirow[b]{2}{*}{ Toplam } & \multirow[b]{2}{*}{$\chi^{2}$} & \multirow[b]{2}{*}{$p$} \\
\hline & & & $\begin{array}{c}\text { Hiç } \\
\text { (SIfir) }\end{array}$ & $\begin{array}{c}500 \text { gr'dan } \\
\text { az }\end{array}$ & $\begin{array}{c}500-999 \\
\text { gr }\end{array}$ & $1000-1999 \mathrm{gr}$ & $\begin{array}{c}2 \mathrm{Kg} \text { ve } \\
\text { üzeri }\end{array}$ & & & \\
\hline \multirow{6}{*}{$\begin{array}{l}\text { Eüitim } \\
\text { Görülen } \\
\text { Veteriner } \\
\text { Fakültesi }\end{array}$} & Mehmet Akif & $n$ & 4 & 15 & 26 & 10 & 5 & 60 & \multirow{6}{*}{8,054} & \multirow{6}{*}{$0,432^{+}$} \\
\hline & Ersoy Üni. & $\% *$ & $6,7 \%$ & $25,0 \%$ & $43,3 \%$ & $16,7 \%$ & $8,3 \%$ & $100,0 \%$ & & \\
\hline & \multirow{2}{*}{ Firat Üni. } & n & 6 & 22 & 35 & 16 & 10 & 89 & & \\
\hline & & $\% *$ & $6,7 \%$ & $24,7 \%$ & $39,3 \%$ & $18,0 \%$ & $11,2 \%$ & $100,0 \%$ & & \\
\hline & \multirow{2}{*}{ Selçuk Üni. } & $n$ & 4 & 38 & 29 & 12 & 10 & 93 & & \\
\hline & & $\% *$ & $4,3 \%$ & $40,9 \%$ & $31,2 \%$ & $12,9 \%$ & $10,8 \%$ & $100,0 \%$ & & \\
\hline \multirow{10}{*}{ Sınıf Düzeyi } & \multirow{2}{*}{ 1.Sinif } & $n$ & 3 & 13 & 11 & 2 & 2 & 31 & \multirow{10}{*}{18,65} & \multirow{10}{*}{$0,291 \dagger$} \\
\hline & & $\% *$ & $9,7 \%$ & $41,9 \%$ & $35,5 \%$ & $6,5 \%$ & $6,5 \%$ & $100,0 \%$ & & \\
\hline & \multirow{2}{*}{ 2.Sinif } & $n$ & 4 & 16 & 21 & 13 & 6 & 60 & & \\
\hline & & $\% *$ & $6,7 \%$ & $26,7 \%$ & $35,0 \%$ & $21,7 \%$ & $10,0 \%$ & $100,0 \%$ & & \\
\hline & $3 S_{\text {ind }}$ & $n$ & 3 & 17 & 21 & 6 & 2 & 49 & & \\
\hline & 3.Sinit & $\% *$ & $6,1 \%$ & $34,7 \%$ & $42,9 \%$ & $12,2 \%$ & $4,1 \%$ & $100,0 \%$ & & \\
\hline & \multirow[b]{2}{*}{ 4.Sinif } & $n$ & 1 & 11 & 21 & 5 & 4 & 42 & & \\
\hline & & $\% *$ & $2,4 \%$ & $26,2 \%$ & $50,0 \%$ & $11,9 \%$ & $9,5 \%$ & $100,0 \%$ & & \\
\hline & \multirow{2}{*}{ 5.Sınıf/İntörn } & n & 3 & 18 & 16 & 12 & 11 & 60 & & \\
\hline & & $\% *$ & $5,0 \%$ & $30,0 \%$ & $26,7 \%$ & $20,0 \%$ & $18,3 \%$ & $100,0 \%$ & & \\
\hline \multirow{12}{*}{$\begin{array}{l}\text { Barınma } \\
\text { Durumu }\end{array}$} & Ailemin & $n$ & 0 & 8 & 10 & 8 & 3 & 29 & \multirow{12}{*}{24,753} & \multirow{12}{*}{$0,21 \dagger$} \\
\hline & Yaninda & $\% *$ & $0,0 \%$ & $27,6 \%$ & $34,5 \%$ & $27,6 \%$ & $10,3 \%$ & $100,0 \%$ & & \\
\hline & \multirow{2}{*}{ Akraba Yanı } & $n$ & 0 & 3 & 1 & 1 & 0 & 5 & & \\
\hline & & $\% *$ & $0,0 \%$ & $60,0 \%$ & $20,0 \%$ & $20,0 \%$ & $0,0 \%$ & $100,0 \%$ & & \\
\hline & \multirow{2}{*}{ Devlet Yurdu } & $n$ & 3 & 11 & 17 & 6 & 2 & 39 & & \\
\hline & & $\% *$ & $7,7 \%$ & $28,2 \%$ & $43,6 \%$ & $15,4 \%$ & $5,1 \%$ & $100,0 \%$ & & \\
\hline & \multirow{2}{*}{ Özel Yurt } & $n$ & 2 & 15 & 9 & 3 & 0 & 29 & & \\
\hline & & $\% *$ & $6,9 \%$ & $51,7 \%$ & $31,0 \%$ & $10,3 \%$ & $0,0 \%$ & $100,0 \%$ & & \\
\hline & \multirow{2}{*}{ Öğrenci Evi } & n & 8 & 37 & 52 & 20 & 20 & 137 & & \\
\hline & & $\% *$ & $5,8 \%$ & $27,0 \%$ & $38,0 \%$ & $14,6 \%$ & $14,6 \%$ & $100,0 \%$ & & \\
\hline & \multirow{2}{*}{ Diğer } & n & 1 & 1 & 1 & 0 & 0 & 3 & & \\
\hline & & $\% *$ & $33,3 \%$ & $33,3 \%$ & $33,3 \%$ & $0,0 \%$ & $0,0 \%$ & $100,0 \%$ & & \\
\hline & & $n$ & $10_{\mathrm{a}, \mathrm{b}}$ & $37 \mathrm{~b}$ & $60_{a}$ & $30_{a}$ & $21_{a}$ & 158 & & \\
\hline Cincivet & Erkek & $\% *$ & $6,3 \%$ & $23,4 \%$ & $38,0 \%$ & $19,0 \%$ & $13,3 \%$ & $100,0 \%$ & 15721 & $0004+$ \\
\hline Cinsiyet & V d & $n$ & $4_{a, b}$ & $38 \mathrm{~b}$ & $30_{a}$ & $8_{a}$ & $4_{a}$ & 84 & $15, / 24$ & $0,004^{+}$ \\
\hline & Kadin & $\% *$ & $4,8 \%$ & $45,2 \%$ & $35,7 \%$ & $9,5 \%$ & $4,8 \%$ & $100,0 \%$ & & \\
\hline $\begin{array}{c}\text { Hayvansal } \\
\text { Gida }\end{array}$ & Evet & $\begin{array}{c}n \\
\%^{*}\end{array}$ & $\begin{array}{c}6_{a} \\
6,3 \%\end{array}$ & $\begin{array}{c}27 \mathrm{a} \\
28,4 \%\end{array}$ & $\begin{array}{c}32_{a} \\
33,7 \%\end{array}$ & $\begin{array}{c}20_{a} \\
21,1 \%\end{array}$ & $\begin{array}{c}10_{a} \\
10,5 \%\end{array}$ & $\begin{array}{c}95 \\
100,0 \%\end{array}$ & & \\
\hline Tüketim & & $n$ & $8 a$ & $48_{a}$ & $58_{a}$ & $18_{a}$ & $15_{a}$ & 147 & 3.783 & $0,441^{+}$ \\
\hline $\begin{array}{l}\text { Düzeyiniz } \\
\text { Sizce Yeterli } \\
\text { mi? }\end{array}$ & Hayır & $\% *$ & $5,4 \%$ & $32,7 \%$ & $39,5 \%$ & $12,2 \%$ & $10,2 \%$ & $100,0 \%$ & $3, / 83$ & 0,441 \\
\hline
\end{tabular}

* Satır yüzdeleri hesaplanmıştır.

† Pearson Exact Ki-Kare Test

+ Continuity Correction Ki-Kare Test 
Tablo 3. Kanatli eti tüketiminde etkili olabilecek ekonomik faktörlerin değerlendirilmesi

Table 3. Evaluation of economic factors that may be effective in poultry meat consumption

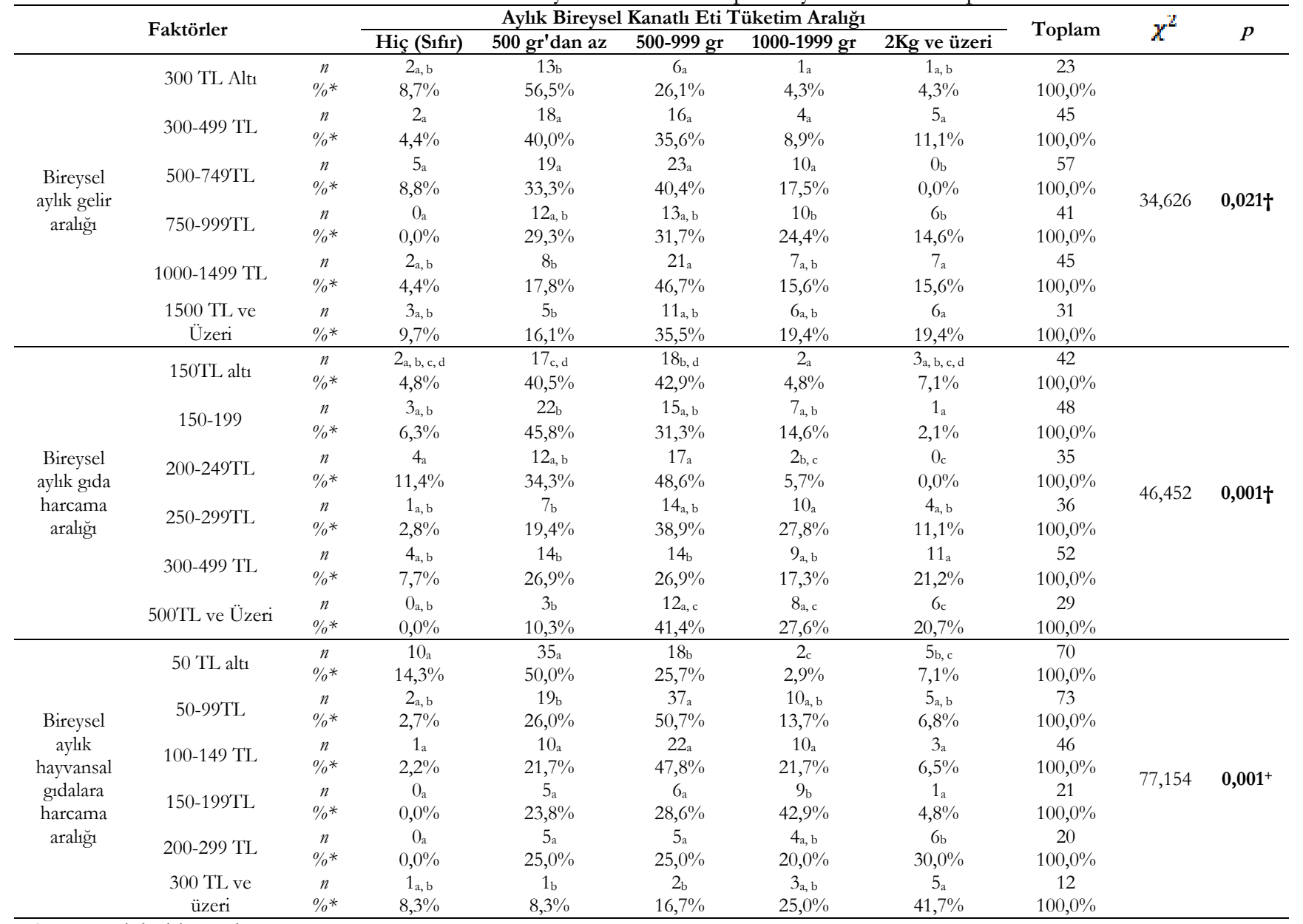

* Satır yüzdeleri hesaplanmıştır.

† Pearson Exact Ki-Kare Test

+ Continuity Correction Ki-Kare Test

\section{TARTIŞMA ve SONUÇ}

Toplumu oluşturan fertlerin yeterli ve dengeli beslenmeleri için gerek devletlere gerekse ailelere büyük görevler düşmektedir. Bu bağlamda en büyük risk grubu olan çocuklara ve gençlere büyüme süreçlerinde gereken desteğin verilmesi ve doğru beslenme eğilimlerinin kazandırılması gerekmektedir. Bu kapsamda Türkiye'de genç nüfusun beslenme alışkanlıkları ve davranışlarının düzenli takip edilerek zamanında ve uygulanabilir politikaların oluşturulması gelecek nesillerin yetiştirilmesinde önem arz etmektedir.

Araştırmanın bulguları konu ile benzer çalısmalar itibariyle değerlendirildiğinde, Cevger ve ark. (2008) tarafindan yapılan çalışmada öğrencilerin aylık bireysel beyaz et tüketimi türlere göre $1 \mathrm{~kg}$ ve üzerinde olan ögrencilerin oranı, tavuk etinde \%60,6 hindi ile diğer kanatlı etlerinde \%2,4 olarak tespit edilmiştir. Yapılan diğer bir çalışmada öğrencilerden \%58,8'nin aylık $1 \mathrm{~kg}$ ve üzerinde beyaz et tükettikleri bildirilmiştir (Sarı̈̈zkan ve ark. 2007). Elazığ'da yapılan bir başka çalışmada ise veteriner fakültesi öğrencilerinin
$\% 21,9$ 'u aylık $1 \mathrm{~kg}$ üzeri kanatlı eti tükettikleri belirtilmiştir (Gökhan 2013). Araştırma kapsamında 1 $\mathrm{kg}$ ve üzerinde kanatlı eti tüketen öğrencilerin \%26 oranında olup diğer çalışmaların çoğuna kıyasla düşük bulunmuştur.

Artvin'de üniversite öğrencilerine yönelik gerçekleştirilen başka bir çalışmada katılımcıların haftalı tavuk eti tüketimi $1,3 \mathrm{~kg}$ düzeyinde bildirilmiştir (İskender ve ark. 2015). Samsun ilinde veteriner fakültesi öğrencileri ile yapılan diğer bir araştırmada ise öğrencilerin aylık kanatlı eti tüketim miktarı $987 \mathrm{~g}$ düzeyinde bulunmuştur (Şentürk 2011). Araştırma kapsamında öğrencilerin aylık kanatlı et tüketim miktarı $1,1 \mathrm{~kg}$ düzeyinde olup veteriner fakültesinde gerçekleşen çalışma ile benzer bulunmuştur.

Araştırma bulgularında tavuk eti tüketim miktarına etkili olabilecek faktörler değerlendirildiğinde; eğitim görülen şehrin, fakültenin, sınıf düzeyinin, barınma durumunun etkili olmadığı görülmektedir (Tablo 1). Bununla kısmen ilişkili bir çalışmada ise gelir grupları arasında yerleşim yerinin gida talepleri üzerine etkili 
olmadığı belirtilmiștir (Șengül 2004). Yaptığımız çalışmada ise sadece cinsiyetin etkili olduğu, bu durumunda erkek öğrencilerde 1-2 kg arası tavuk eti tüketenlerin sayısının daha fazla olması ve toplam tavuk eti tüketiminin erkek öğrencilerde bayan ögrencilere göre daha fazla olması durumlarından kaynaklanmaktadır. Hayvansal gıda tüketim düzeyini yeterli bulup bulmama fikri ile beyaz et tüketim miktarı arasında anlamlı ilișki bulunmamasının nedenin veteriner fakültesi öğrencilerinin büyük bir çoğunluğunun tüketim düzeyini yeterli görmeyişinden kaynaklandığ tahmin edilmektedir.

Kanatlı eti tüketiminde etkili olan faktörler bireysel aylik gelir, bireysel aylik gida harcaması ve bireysel aylik hayvansal gida harcama düzeyi olarak tespit edilmiştir. Aylık bireysel gelir arttıkça kanatlı eti tüketimi diğer çalışmalarla benzer olarak artmıştır (Sarı̈̈zkan ve ark. 2007). 500-749 TL aralığına kadar kanatlı eti tüketenlerin sayıs1 önce artmakta, sonrasında gelir artmaya devam ettikçe kanatlı eti tüketenlerin sayısı azalmaktadır. Gelir belirli bir noktaya kadar artarken kanatlı eti tüketimi önce artmakta, gelir artmaya devam ettikçe kanatlı eti tüketim miktarı azalmaktadır. Gelir artınca kanatlı eti haricindeki diğer et ve et ürünlerinin tercih edilmesinden dolayı bu durumun şekillendiği tahmin edilmektedir.

Gida harcama oranları gruplar arasinda dengeli sayılabilecek bir dağllım göstermesine karşın, hayvansal gidalara yapılan harcama gruplarında ise düşük harcama gruplarında yoğunlaşmanın olması dikkat çekici niteliktedir. Öğrencilerin gida bütçesinde fiyatları daha düşük nitelikte olan hayvansal olmayan gidalara ağırlık verdiği, hayvansal ürünlerde asgari düzeyde bütçe ayırarak tüketimde bulundukları anlaşılmaktadır.

Buradan hareketle Türkiye'de yaşanacak ekonomik iyileşme ve refah artş̧larına bağlı olarak, öğrenci gelirlerinin artmasına imkân olanak sağlayacak gelişmelerle öğrencilerin bireysel gıda harcamaları da artacaktır. Buna bağlı olarak öncelikli olarak hayvansal gidalara olan talep artacak, bunlar arasinda da hayvansal et ve et ürünlerinde fiyatı ve ulaşılabilirliği ilk sırada gelen kanatlı etine olan talebin artması söz konusu olacaktır (Erdoğan ve Çiçek 2015). Gelir artmas1 haricinde ise üretim maliyetlerinin aşağ çekilmesine olanak sağlayacak bir takım destek, teşvik ve tedbirlerinde dolaylı olarak tüketicilerin satın alma gücünü artıracağından dolayı, üniversite öğrencilerinin de kanatlı etine olan talebini artıracaktır.
TEŞEKKÜR

2. Uluslararası Sağhık Bilimleri ve Yaşam Kongresi, sözlü sunum.

Mebmet Akif Ersoy Üniversitesi GO 2018/106 saynl Girişimsel Olmayan Klinike Arastırmalar Etik Kurulu olur karar.

\section{KAYNAKLAR}

Akçay A, Sarıözkan S, Al S. Akademik personelin et tüketim tercihlerinin analitik hiyerarşi prosesi ile değerlendirilmesi. Veteriner Hekimler Derneği Dergisi. 2018; 89(1): 11-24.

Akın AC, Çevrimli MB, Arıkan MS, Tekindal MA. Determination of the causal relationship between beef prices and the consumer price index in Turkey. Turk J Vet Anim Sci. 2019; 43: 353-358.

Anonymous. OECD, Kiși bașı et tüketim miktarları. https://data.oecd.org/agroutput/meat-consumption.htm Accessien date: 24.08.2019

Aral Y, Aydın E, Demir P, Akın AC, Cevger Y, Kaya Kuyululu ÇY, Arıkan MS. Consumer preferences and consumption situation of chicken meat in Ankara province, Turkey. Turk J Vet Anim Sci. 2013; 37(5): 582587.

Arıkan MS, Çevrimli MB, Akın AC, Tekindal MA. Determining the change in retail prices of veal in Turkey by GARCH method between 2014-2017. Kafkas Univ Vet Fak Derg. 2019; 25(4): 499-505.

Ayhan DE, Günaydın E, Gönlüaçık E, Arslan U, Çetinkaya F, Asımı H, Uncu Y. Uludağ Üniversitesi Tip Fakültesi öğrencilerinin beslenme alışkanlıkları ve bunları etkileyen faktörler. Uludăg Üniversitesi Tip Fakültesi Dergisi. 2012; 38(2): 97-104.

Bazga B, Ipate I, Ipate N. Price volatility in context of food security for sustainable development. Competitiveness of Agro-Food and Environmental Economy. 2014; 198-204.

Botev Z, Ridder A. Variance Reduction. Wiley StatsRef: Statistics Reference Online: 1--6. 2017.

Cevger Y, Aral Y, Demir P, Sarıözkan S. Ankara Üniversitesi Veteriner Fakültesi intern öğrencilerinde hayvansal ürünlerin tüketim durumu ve tüketici tercihleri. $A U V F D$. 2008; 55: 189-194.

Erdoğan N, Çiçek H. Hayvansal gıdaların tüketim yapısı ve tüketici tercihlerinin belirlenmesi üzerine bir araștırma: Üniversite personeli örneği. Kocatepe Veterinary Journal. 2015; 8: 25-31.

Erdoğdu H, Çiçek H. Modelling beef consumption in Turkey: the ARDL/bounds test approach. Turk J Vet Anim Sci. 2017; 41(2): 255-264.

Eştürk Ö, Albayrak N. Investigation of the relationship between agricultural products-food price increases and inflation. ÜIIIID-IJEAS. 2018; (18. EYİ Özel Say1): 147158.

Gökhan EE. The situation of animal product consumption and preferences among final-year students at Firat University, faculty of veterinary medicine. Journal of Animal and Veterinary Advances. 2013; 12(1): 38-41.

Hernandez MA, Ibarra R, Trupkin DR. How far do shocks move across borders? Examining volatility transmission in major agricultural futures markets. European Review of Agricultural Economics. 2013; 41(2): 301-325. 
İskender H, Kanbay Y, Özçelik E. Artvin Çoruh Üniversitesi öğrencilerinin tavuk eti tüketim tercihleri. SBVD. 2015; 29: 09-13.

Kızılaslan H, Nalıncı S. Amasya ili merkez ilçedeki hane halkının kanatlı eti tüketim alışkanlıkları ve kanatlı eti tüketimini etkileyen faktörler. GBAD. 2013; 6: 1-18.

Sarıözkan S, Cevger Y, Demir P, Aral Y. Erciyes Üniversitesi Veteriner Fakültesi öğrencilerinin hayvansal ürün tüketim yapısı ve alışkanlıkları. JHS. 2007; 16: 171-179.

Sarris A. Food commodity price volatility and food insecurity. Bio-based and Applied Economics. 2013; 2(3): 213-236.

Şengül S. Türkiye'de gelir gruplarına göre gıda talebi. ODTÜ Gelisim Dergisi. 2004; 31: 115-148.

Şentürk B. Ondokuz Mayıs Üniversitesi Veteriner Fakültesi öğrencilerinin hayvansal ürün tüketim harcamalarının analizi. Veteriner Hekimler Derneği Dergisi. 2011; 82: 71-78.

Shahrokh Esfahani M, Dougherty ER. Effect of separate sampling on classification accuracy. Bioinformatics. 2014; 30(2): 242-250. 